\title{
Gastroesophageal Reflux Disease and Helicobacter pylori: What May Be the Relationship?
}

\author{
Uday C Ghoshal, MD, DNB, DM, FACG* and Dipti Chourasia, PhD \\ Department of Gastroenterology, Sanjay Gandhi Postgraduate Institute of Medical Sciences, Lucknow, India
}

\begin{abstract}
Relationship between Helicobacter pylori $(H$. pylori) and gastroesophageal reflux disease (GERD) is controversial. We aimed to review the possible relationship between $H$. pylori infection and GERD. Epidemiological data indicate an inverse relationship between frequency of $H$. pylori infection and prevalence of GERD and its complications like Barrett's esophagus and esophageal adenocarcinoma. H. pylori eradication in patients with peptic ulcer disease may be associated with increased risk of development of GERD compared with untreated patients. Infection with cagA bearing strains of $H$. pylori was associated with less severe GERD including endoscopic esophagitis, possibly due to pangastritis leading to hypochlorhydria. Recent studies on inflammatory markers (IL-1 $\beta$ and IL-1RN) suggest pro-inflammatory genotypes to be protective against development of severe GERD, especially in patients with $H$. pylori infection. Identification of candidate genes playing an important role in gastric acid secretion and visceral hypersensitivity to the esophageal epithelium might help in early detection of individuals susceptible to develop GERD. Interplay between $\mathrm{H}$. pylori and host factors play an important role in the pathogenesis of GERD.
\end{abstract}

(J Neurogastroenterol Motil 2010;16:243-250)

\section{Key Words}

Esophagitis, Gastric acid, Gastritis, Genes

\section{Introduction}

Gastroesophageal reflux disease (GERD) is a common condition, often associated with impairment in health-related quality of life. ${ }^{1}$ Esophageal acid exposure in patients with GERD may be severe enough to cause endoscopically visible mucosal damage (erosive esophagitis), which is graded by Los Angeles classification, ${ }^{2}$ peptic esophageal stricture, and Barrett's esophagus (BE). In a good proportion of patients, there is no endoscopically visible mucosal damage of esophageal mucosa in spite of symptoms of GERD and esophageal acid exposure. This condition is termed as endoscopy-negative reflux disease (ENRD). Recent reports indicate ENRD to be quite common all over the world. ${ }^{3}$

Several factors may influence the severity of GERD. Esophageal acid exposure not only depends on reflux of gastric contents into esophagus and failure of esophagus to clear it by peristaltic contractions but also on $\mathrm{pH}$ of the refluxed gastric juice. ${ }^{4,5} \mathrm{pH}$ of gastric juice depends on acid secretory capacity of oxyntic or parietal cells. Helicobacter pylori (H. pylori) infection is common in many parts of the world. Since GERD is also a com-

Received: May 9, 2010 Revised: July 1, 2010 Accepted: July 2, 2010

(c) This is an Open Access article distributed under the terms of the Creative Commons Attribution Non-Commercial License (http://creativecommons. org/licenses/by-nc/3.0) which permits unrestricted non-commercial use, distribution, and reproduction in any medium, provided the original work is properly cited.

*Correspondence: Uday C Ghoshal MD, DNB, DM, FACG

Department of Gastroenterology, Sanjay Gandhi Postgraduate Institute of Medical Sciences, Raebareli Road, Lucknow 226014, India

Tel: +91-962-884-2456, Fax: +91-522-266-8017, E-mail: udayghoshal@gmail.com

Financial support: Part of data included in this review was supported by an extramural research grant from Department of Biotechnology (No.

Conflicts of interest: None. BT/PR10141/MED/30/65/2007), Govt. of India to UCG. 
mon condition, co-existence of this disease and $H$. pylori infection is quite expected. What could be the relationship between $H$. $p y$ lori infection and occurrence and severity of GERD? Most studies suggest that $H$. pylori may protect against development of GERD or may reduce its severity, ${ }^{6-9}$ however, a few studies do suggest that it may aggravate GERD. ${ }^{10,11}$ Supportive evidences discussed below will elucidate the possible relationship between GERD and H. pylori.

\section{Epidemiological Studies Regarding the Relationship Between GERD and $H$. pylori Infection}

Frequency of $H$. pylori infection is lower in people from developed countries such as North America, Western Europe and Australia $^{12-14}$ whereas that of GERD and its complications are more frequent among them. ${ }^{15-17}$ In contrast, frequency of $H$. pylo$r i$ infection is higher in people from developing nations such as South America, Eastern Europe, Africa, China and India ${ }^{18-22}$ while that of GERD and its severity is lower among them. ${ }^{19,23-26}$ Furthermore, there is decline in incidence of peptic ulcer disease and distal gastric carcinoma globally but increase in GERD and its complications such as $\mathrm{BE}$ and esophageal adenocarcinoma (EAC). ${ }^{6,27,28}$ Moreover, frequency of $H$. pylori infection is also decreasing worldwide due to better hygiene and increasing use of antibiotics. ${ }^{29}$ Therefore, one can assume a possible negative relation between $H$. pylori infection and frequency and severity of GERD.

\section{Asian perspective}

Asian data also support an inverse relationship between GERD and its complications and $H$. pylori infection. Data from Korea showed that prevalence of reflux esophagitis was $7.9 \%$ and majority of patients had mild grades of disease (Los Angeles classification A and B), ${ }^{30}$ and frequency of BE was low $(0.84 \%) .{ }^{31} \mathrm{~A}$ study from China suggested that the prevalence of erosive esophagitis and $\mathrm{BE}$ was $4.3 \%$ and $1.0 \%$, respectively and $H$. pylori was negatively associated with erosive esophagitis. ${ }^{32}$ One of the reasons for increase in prevalence of GERD in Japan in recent years is thought to be due to decrease in $H$. pylori infection rate ${ }^{33}$ and absence of $H$. pylori infection was one of the risk factors for occurrence of GERD in another study. ${ }^{34}$ Hence, most studies suggest a possible protective role of $H$. pylori against GERD.

\section{Evidences From H. pylori Eradication Studies}

It is well-established that eradication of $H$. pylori heals peptic ulcer and prevents its recurrence. Increased severity of GERD and its complications such as BE after successful eradication of H. pylori in patients with or without peptic ulcer has been documented in several studies. ${ }^{7,8,35-37}$ Others reported de novo development or exacerbation of GERD after treatment of $H$. pylori ${ }^{38,39}$ particularly among Asians compared to North Americans and Europeans. ${ }^{40}$ Development of GERD following eradication of H. pylori may reflect an increase in the acidity of the refluxate superimposed on pre-existing abnormalities in gastroesophageal motility. Conversely, some studies did show beneficial effect of H. pylori eradication on symptoms of GERD. ${ }^{41,42}$

In a meta-analysis by Yaghoobi et $\mathrm{al}^{43}$ though frequency of GERD was not found to be higher after eradication of $H$. pylori among dyspeptic patients, there was two folds increased risk of its development with successful eradication among patients with peptic ulcer compared to untreated controls. What could be the explanation for this? It is possible that the dyspeptic patients already had irreversible reduction in gastric acid secretion due to pangastritis in contrast to those with peptic ulcer, who are known to have increased parietal cell mass causing hyperchlorhydria. This meta-analysis therefore, may suggest a possible protective role of $H$. pylori infection against the development of GERD at least among patients with peptic ulcer.

\section{Asian perspective}

Data from Asia on this issue is scant. A study from Japan showed improvement in pre-existing reflux esophagitis after $H$. $p y$ lori eradication in patients with GERD associated with duodenal ulcer. $^{44}$ These results are contradictory to most other studies. Fujiwara explained the mechanism of such results as follows: (1) normalization of gastric acidity in patients with duodenal ulcer might play an important role, (2) secondly, heartburn and/or acid regurgitation might be confused with symptoms of peptic ulcer disease; hence, the symptoms might be felt as improved after the cure of $H$. pylori infection and (3) lastly, if peptic ulcer itself directly or indirectly induced GERD, healing of the ulcer might result in improvement of GERD. ${ }^{33}$ Hence, patients having GERD with peptic ulcer were benefited by the $H$. pylori eradication therapy. Furthermore, in Japan H. pylori should be eradicated in patients with GERD as well due to high incidence of gastric cancer. ${ }^{45}$ 


\section{Mechanism of Gastric Acid Alteration by H. pylori and Its Relationship} With GERD

H. pylori infection leads to gastritis that might alter gastric acid secretion. The degree and extent of gastritis may be related to host genetic or agent (H. pylori strains) factors.

\section{H. pylori, gastritis and gastric acid secretion altering GERD severity}

H. pylori may influence gastric acid secretion in 2 ways: (1) limited inflammation in the gastric antrum is associated with destruction of somatostatin secreting D-cells. ${ }^{46}$ Thus, there is loss of negative feedback on gastric acid secretion resulting in increased parietal cell mass and hyperchlorhydria, which may increase severity of GERD and (2) pangastritis (more often associated with cytotoxin-associated gene A $[\operatorname{cag} A]$ and vacuolating cytotoxin [VacAs1] bearing strains) leads to destruction of acid secreting parietal cells of gastric corpus, causing gastric atrophy with consequent hypo- or achlorhydria (Fig. 1); this may reduce the severity of GERD and its complications. A review by Sharma and Vakil also suggested a negative association between the prevalence of $H$. pylori infection especially cag $A$ bearing strains and $\mathrm{BE}$ and $\mathrm{EAC}{ }^{28}$

A study from Taiwan showed that only $33 \%$ of 276 patients with reflux esophagitis had $H$. pylori infection compared with $67.5 \%$ of 378 with normal esophagus. Triple virulent (cagA, blood-group antigen-binding adhesion gene [babA2] and vacAs1a) genotype of $H$. pylori was also uncommon among patients with reflux esophagitis. ${ }^{47}$ In a study from Hong Kong, the prevalence of H. pylori infection among 225 patients with GERD was $34 \%$; $H$. pylori infected patients had less severe esophagitis than those without it. Of those infected with $H$. pylori, 70\%, 76\% and $78 \%$ of ENRD, erosive oesophagitis and control subjects, respectively were $\operatorname{cag} A$ positive. ${ }^{48}$ Protective effect of $\operatorname{cag} A$ positive strains of H. pylori against GERD has also been shown in Iran. ${ }^{49}$ Another multi-ethnic study from Malaysia suggested that cagA-positive strains of $H$. pylori was associated with reduced severity of GERD among Indians. ${ }^{50}$ As prevalence of cag $A$ bearing strains of H. pylori is high in some developing countries, ${ }^{51}$ frequent occurrence of hypochlorhydria may protect against development of severe GERD and its complications in these areas of the world.

\section{Endoscopic severity of GERD and $H$. pylori infection}

Patients with severe GERD (higher Los Angeles grades) are less often infected with $H$. pylori. ${ }^{3,52,53}$ Also, cagA bearing strains of $H$. pylori is more frequent in patients with ENRD than those with endoscopic reflux disease and its sequel, ${ }^{54}$ suggesting the protective role of these strains of bacteria against development of severe GERD.

\section{Host Factors}

Final outcome following exposure to a disease-causing agent is also influenced by the host factors. Not only the environmental

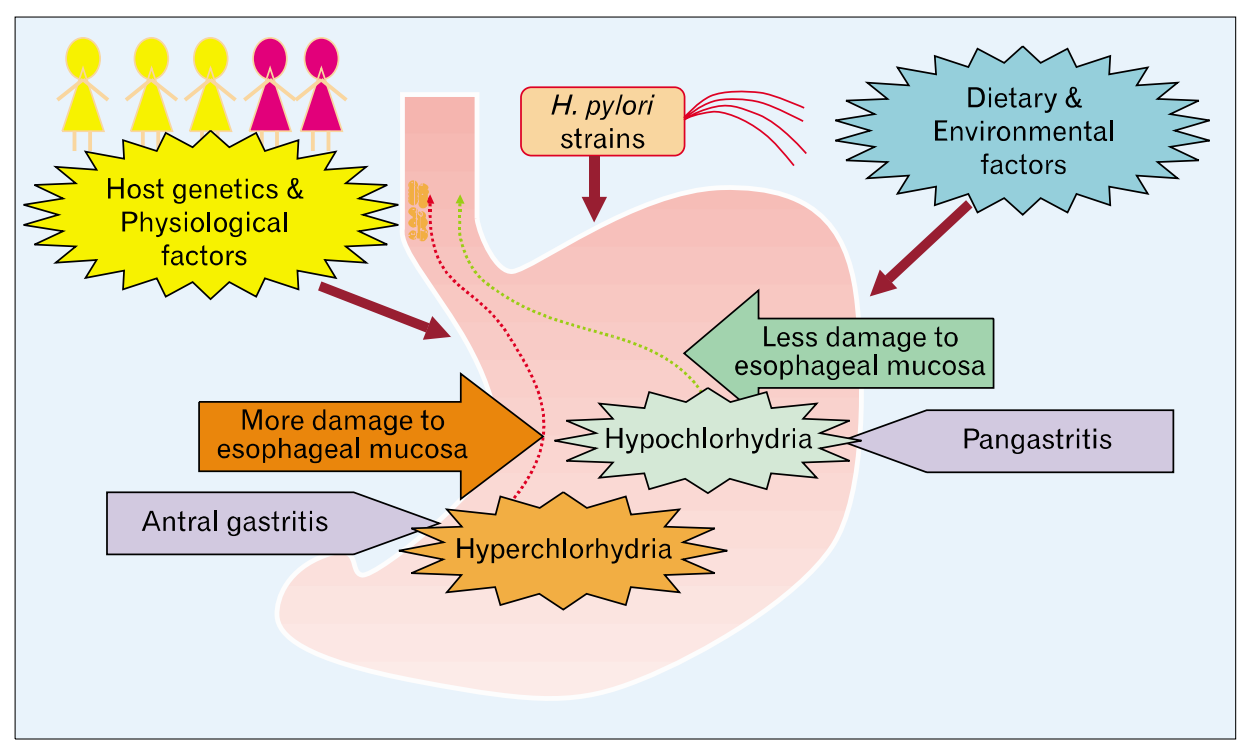

Figure 1. Possible role of various factors including $H$. pylori in pathogenesis of gastroesophageal reflux disease. 
or dietary factors, but host physiological as well as genetic factors may play important role in the pathogenesis of GERD. Role of host physiological factors, such as hypotensive lower esophageal sphincter, transient lower esophageal sphincter relaxations, delayed gastric emptying, presence of hiatus hernia, hypoperistalsis of esophagus are well established in pathogenesis of GERD. ${ }^{55,56}$ However, there is still inadequate literature on host genetic factors, which may influence development of GERD. Also, the clearance of $H$. pylori may be related to host genetic factors in addition to differences between strains. ${ }^{57}$

Importance of the genetic factors in GERD is supported by recent reports that showed that there is increased concordance for GERD in monozygotic twin pairs as compared to dizygotic pairs, indicating genetic rather than shared environmental effect. ${ }^{58,59}$ Limited studies have shown that IL-1B-511C allele, ${ }^{60} \mathrm{IL}-1 \mathrm{~B}-31 \mathrm{~T}$ allele, ${ }^{61} \mathrm{G}$ protein beta 3 subunit $825 \mathrm{~T}$ allele, ${ }^{62} \mathrm{IL}-1 \mathrm{RN}+2018$ $2 / 2$ genotype, ${ }^{61} 2 / 2$ genotype of IL-10-1082, ${ }^{63}$ homozygous extensive of CYP2C $19,{ }^{64} \mathrm{~b}$ allele ( $\mathrm{val}^{105}$ ) of glutathione S-transferase $\mathrm{P} 1{ }^{65,66} \mathrm{~A} / \mathrm{A}$ genotype of cyclin D1 (CCND1) G870A ${ }^{67}$ and homozygous variant of Xeroderma pigmentosum complementary group C poly (AT) insertion/deletion polymorphism gene $^{68}$ are the potential risk factors for either GERD or its complications such as BE and EAC.

\section{Possible Molecular Mechanisms}

\section{H. pylori and gastric acid alteration}

H. pylori infection induces a substantial inflammatory reaction in the gastric mucosa with recruitment of leukocytes and over-expression and release of pro-inflammatory cytokines. This inflammation may be due to the secreted proteins from $H$. pylori, which initiate a cascade of signaling events within the host cells resulting in up regulation of several inflammatory mediators. Various bacterial factors, which may reduce gastric acid secretion and thereby severity of GERD are as follows: (1) VacA, especially the virulent form s $1 \mathrm{~m} 1$, inhibits gastric acid secretion by disrupting the apical membrane-cytoskeletal interaction in gastric parietal cells $^{69}$ : this may reduce esophageal acid exposure; (2) bacterial lipopolysaccharides ${ }^{70}$ reduces gastric acid secretion through prostaglandin system ${ }^{71}$ and by inhibition of $\mathrm{H}^{+} / \mathrm{K}^{+}$ATPase enzymatic function or changes in cytoskeletal rearrangements in $\mathrm{H}^{+} / \mathrm{K}^{+}$-ATPase subunits rather than by down-regulation of transcriptional or translational events ${ }^{72}$; (3) CagA protein, encoded by $c a g A$ gene, is a part of $c a g$ pathogenicity island.
This is translocated into the host cells by Type-IV secretion apparatus. Once translocated, it undergoes tyrosine phosphorylation at the Glu-Pro-Ile-Tyr-Ala motif. The presence of a single Glu-Pro-Ile-Tyr-Ala motif is necessary for the membrane localization of CagA. ${ }^{73}$ CagA injection into the host gastric epithelial cell can induce NF- $\kappa \mathrm{B}$ activation and IL-8 production. ${ }^{74}$ Thus, infection with cagA positive strains may lead to more inflammation in the stomach, causing hypochlorhydria; (4) Other H. pylori proteins, such as outer membrane inflammatory protein, is considered to be important in stimulation of IL-8 secretion, even in cag-negative strains, though to a much lesser extent ${ }^{75}$ and (5) H. pylori neutrophil activating protein can induce neutrophils to produce reactive oxygen radicals damaging gastric epithelium. ${ }^{76}$

\section{Genetic factors in susceptibility to GERD}

Limited studies have shown that host genetic factors that may influence development of GERD include genes, which may alter gastric acid secretion (pro and anti-inflammatory factors and those involved in acid secretory pathway), ${ }^{60,77}$ DNA repair pathway (for BE and EAC), ${ }^{68,78}$ carcinogen detoxification pathway (for EAC), ${ }^{65,79,80}$ cell cycle regulatory pathway ${ }^{67,81}$ and visceral hypersensitivity $^{62}$ to the refluxed acid in esophagus (Fig. 1). Recently, visceral hypersensitivity has been shown to be involved in the pathogenesis of GERD. Patients with GERD may have normal esophageal acid exposure, but their esophageal mucosa can be more sensitive to the acid reflux, leading to heartburn and erosive esophagitis due to visceral neural pathway dysfunction. $^{62,82,83}$ It is also elucidated that one of the major reasons for heartburn among patients with ENRD may be related to esophageal visceral hypersensitivity. ${ }^{84,85} \mathrm{~A}$ recent study revealed role of host genetic polymorphism of G-protein beta 3 subunit gene (G-protein-coupled receptors intervene the response to acid, neurotransmitters and humoral factors transforming esophageal sensory function) in the enhanced perception of reflux events. ${ }^{62}$ However, more research is needed on several other candidate genes, which could be potentially involved in the above mentioned pathways.

In summary, infection with $H$. pylori may lead to gastric inflammatory response, which could be either antral or corpus, depending on the $H$. pylori strain and host genetic and environmental factors. 


\section{Interplay of host genetic factors, $H$. pylori and intes- tinal helminthes}

Since $H$. pylori is an extra-cellular organism, a Th2-cell response (IL-4, IL-5, IL-10, IL-13 and TGF- $\beta$ ) would favor the host to clear the bacteria and prevent occurrence of chronic infection. Paradoxically, H. pylori-specific gastric mucosal T cells generally present a Th1 phenotype (IFN- $\gamma$, IFN- $\beta$, TNF, IL-2 and IL-1 $\beta$; cell mediated immune response). ${ }^{86}$ It has been shown that infection with intestinal helminthes induces Th2-associated IgG1 responses to $H$. pylori infection. ${ }^{87}$ Hence, intestinal helminthes infection may clear the infection by promoting Th2-polarizing immune responses to $H$. pylori. Some of these cytokine polymorphisms have been shown to affect the degree of gastritis. $^{88-94}$

In developing nations, prevalence of $H$. pylori infection as well as that of helminthes is high because of poor hygienic conditions. If an individual gets an infection with helminthes first, they will have Th2 predominant cytokine profile, hence preventing persistent $H$. pylori colonization. On the other hand, if an individual has concomitant infection with $H$. pylori and helminthes (the possibility of which is more common), they might show an intermediate Th1 and Th2 cytokine profile. Thus, a balance between Th1 and Th2 responses may be important in degree of persistence of $H$. pylori infection. This might decide the degree of gastric inflammation and hence, the severity of GERD.

H. pylori infection also activates expression of chemokines such as IL-8 and Gro- $\alpha$. But, their expression is dependent on the corresponding expression of their receptors (CXCR1 and CXCR2) on neutrophils. ${ }^{95}$ IL-8 may influence development of gastritis and duodenal ulcer in patients with $H$. pylori infection. ${ }^{96,97}$

Possible role of other factors such as Gro- $\alpha$, monocyte chemoattractant protein-1 (MCD-1) and CXCR1 and CXCR2 receptors in pathogenesis of $H$. pylori infection and GERD can be studied. These molecular mechanisms suggest a complex interplay between various host factors, agent and environmental factors, which decides the final outcome of the disease.

\section{Conclusion}

Most epidemiological as well as eradication studies suggests a possible protective role of $H$. pylori infection against GERD. Recent data on the role of host genetic factors suggest possible mechanism of influence of $H$. pylori in the pathogenesis of
GERD. Latest studies targeting the role of inflammatory markers (IL-1B and IL-1RN) suggest that presence of the pro-inflammatory genotypes are associated with less severe GERD. ${ }^{60,61,77}$ Polymorphism studies on genes for visceral hypersensitivity, GNB3 also supports that patients with GERD experience enhanced perception of reflux events. ${ }^{62}$ Hence, interplay between both agent (H. pylori) as well as host factors play an important role in the pathogenesis of GERD.

Study of role of host genetic factors in the pathogenesis of GERD will be the major thrust area for research in near future, as there is scanty data on it. Identification of candidate genes playing role in gastric acid secretion and visceral hypersensitivity to the esophageal epithelium might help in early detection of individuals susceptible to develop GERD. Furthermore, a simultaneous study of these genetic polymorphisms with $H$. pylori infection, dietary and life style factors such as obesity, ${ }^{98}$ presence of gall stones, ${ }^{99}$ smoking, ${ }^{98}$ and conditions like chronic laryngitis ${ }^{100}$ and chronic obstructive pulmonary disease, ${ }^{101}$ which are known to be associated with GERD, would be important in evaluating their combined effect on risk of GERD. This may help to undertake preventive strategies for individuals at risk through life style changes.

\section{References}

1. Flook NW, Wiklund I. Accounting for the effect of GERD symptoms on patients' health-related quality of life: supporting optimal disease management by primary care physicians. Int J Clin Pract 2007;61:2071-2078.

2. Lundell LR, Dent J, Bennett JR, et al. Endoscopic assessment of oesophagitis: clinical and functional correlates and further validation of the Los Angeles classification. Gut 1999;45:172-180.

3. Ghoshal UC, Chourasia D, Tripathi S, Misra A, Singh K. Relationship of severity of gastroesophageal reflux disease with gastric acid secretory profile and esophageal acid exposure during nocturnal acid breakthrough: a study using 24 -h dual-channel $\mathrm{pH}$-metry. Scand J Gastroenterol 2008;43:654-661.

4. Collen MJ, Johnson DA, Sheridan MJ. Basal acid output and gastric acid hypersecretion in gastroesophageal reflux disease. Correlation with ranitidine therapy. Dig Dis Sci 1994;39:410-417.

5. Gardner JD, Sloan S, Robinson M, Miner PB Jr. Frequency analyses of gastric $\mathrm{pH}$ in control and gastro-oesophageal reflux disease subjects treated with a proton-pump inhibitor. Aliment Pharmacol Ther 2004;20:1381-1386.

6. Falk GW. GERD and H. pylori: is there a link? Semin Gastrointest Dis 2001;12:16-25.

7. Fallone CA, Barkun AN, Friedman G, et al. Is Helicobacter pylori eradication associated with gastroesophageal reflux disease? Am J Gastroenterol 2000;95:914-920.

8. Haruma K. Review article: influence of Helicobacter pylori on gas- 
tro-oesophageal reflux disease in Japan. Aliment Pharmacol Ther 2004;20(suppl 8):40-44.

9. Gisbert JP, Pajares JM, Losa C. Helicobacter pylori and gastroesophageal reflux disease: friends or foes? Hepatogastroenterology 1999;46:1023-1029.

10. El-Omar EM, Penman ID, Ardill JE, Chittajallu RS, Howie C, McColl KE. Helicobacter pylori infection and abnormalities of acid secretion in patients with duodenal ulcer disease. Gastroenterology 1995;109:681-691.

11. Vicari J, Falk GW, Richter JE. Helicobacter pylori and acid peptic disorders of the esophagus: is it conceivable? Am J Gastroenterol 1997;92:1097-1102.

12. Simon JA, Hudes ES, Perez-Perez GI. Relation of serum ascorbic acid to Helicobacter pylori serology in US adults: the Third National Health and Nutrition Examination Survey. J Am Coll Nutr 2003; 22:283-289.

13. Lin SK, Lambert JR, Nicholson L, Lukito W, Wahlqvist M. Prevalence of Helicobacter pylori in a representative Anglo-Celtic population of urban Melbourne. J Gastroenterol Hepatol 1998;13: 505-510.

14. Seery JP, Henshaw DJ, Sandhu PJ, et al. Helicobacter pylori infection and upper gastrointestinal patholgy in a British immigrant Indian community. Eur J Gastroenterol Hepatol 1997;9:191-194.

15. Nastaskin I, Mehdikhani E, Conklin J, Park S, Pimentel M. Studying the overlap between IBS and GERD: a systematic review of the literature. Dig Dis Sci 2006;51:2113-2120.

16. Mohammed I, Nightingale P, Trudgill NJ. Risk factors for gastro-oesophageal reflux disease symptoms: a community study. Aliment Pharmacol Ther 2005;21:821-827.

17. Talley NJ, Boyce P, Jones M. Identification of distinct upper and lower gastrointestinal symptom groupings in an urban population. Gut 1998;42:690-695.

18. Reshetnikov OV, Häivä VM, Granberg C, Kurilovich SA, Babin VP. Seroprevalence of Helicobacter pylori infection in Siberia. Helicobacter 2001;6:331-336.

19. Segal I. The gastro-oesophageal reflux disease complex in sub-Saharan Africa. Eur J Cancer Prev 2001;10:209-212.

20. Singh K, Ghoshal UC. Causal role of Helicobacter pylori infection in gastric cancer: an Asian enigma. World J Gastroenterol 2006; 12:1346-1351.

21. Mattana C, Vega A, Gómez P, Puig de Centorbi O. Serological profile of Helicobacter pylori infection in the population of San Luis (Argentina). Enferm Infecc Microbiol Clin 2004;22:227-229.

22. Jun ZJ, Lei Y, Shimizu Y, Dobashi K, Mori M. High seroprevalence of Helicobacter pylori in chronic bronchitis among chinese population. Tohoku J Exp Med 2006;208:327-331.

23. Chiocca J, Olmos J, Salis G, Soifer L, Higa R, Marcolongo M; Argentinean Gastro-oesophageal Reflux Study Group. prevalence, clinical spectrum and atypical symptoms of gastro-oesophageal reflux in Argentina: a nationwide population-based study. Aliment Pharmacol Ther 2005;22:331-342.

24. Papatheodoridis GV, Karamanolis DG. Prevalence and impact of upper and lower gastrointestinal symptoms in the Greek urban general population. Scand J Gastroenterol 2005;40:412-421.

25. Wong WM, Lai KC, Lam KF, et al. Prevalence, clinical spectrum and health care utilization of gastro-oesophageal reflux disease in a
Chinese population: a population-based study. Aliment Pharmacol Ther 2003;18:595-604.

26. Shah SS, Bhatia SJ, Mistry FP. Epidemiology of dyspepsia in the general population in Mumbai. Indian J Gastroenterol 2001; 20:103-106

27. el-Serag HB, Sonnenberg A. Opposing time trends of peptic ulcer and reflux disease. Gut 1998;43:327-333.

28. Sharma P, Vakil N. Review article: Helicobacter pylori and reflux disease. Aliment Pharmacol Ther 2003;17:297-305.

29. Ahmed KS, Khan AA, Ahmed I, et al. Impact of household hygiene and water source on the prevalence and transmission of Helicobacter pylori: a South Indian perspective. Singapore Med J 2007;48: 543-549.

30. Shim KN, Hong SJ, Sung JK, et al. Clinical spectrum of reflux esophagitis among 25,536 Koreans who underwent a health check-up: a nationwide multicenter prospective, endoscopy-based study. J Clin Gastroenterol 2009;43:632-638.

31. Park JJ, Kim JW, Kim HJ, et al. The prevalence of and risk factors for Barrett's esophagus in a Korean population: A nationwide multicenter prospective study. J Clin Gastroenterol 2009;43:907-914.

32. Peng S, Cui Y, Xiao YL, et al. Prevalence of erosive esophagitis and Barrett's esophagus in the adult Chinese population. Endoscopy 2009;41:1011-1017.

33. Fujiwara Y, Arakawa T. Epidemiology and clinical characteristics of GERD in the Japanese population. J Gastroenterol 2009;44: 518-534.

34. Miyamoto M, Haruma K, Kuwabara M, Nagano M, Okamoto T, Tanaka M. High incidence of newly-developed gastroesophageal reflux disease in the Japanese community: a 6-year follow-up study. J Gastroenterol Hepatol 2008;23:393-397.

35. Ahmed N, Sechi LA. Helicobacter pylori and gastroduodenal pathology: new threats of the old friend. Ann Clin Microbiol Antimicrob 2005;4:1.

36. Tanaka I, Tatsumi Y, Kodama T, et al. Effect of Helicobacter pylori eradication on gastroesophageal function. J Gastroenterol Hepatol 2004;19:251-257.

37. Carroll IM, Khan AA, Ahmed N. Revisiting the pestilence of Helicobacter pylori: insights into geographical genomics and pathogen evolution. Infect Genet Evol 2004;4:81-90.

38. Nakajima S, Hattori T. Active and inactive gastroesophageal reflux diseases related to Helicobacter pylori therapy. Helicobacter 2003; 8:279-293

39. Sakata H, Fujimoto K. Barrett's esophagus and Helicobacter pylori. Nippon Rinsho 2005;63:1383-1386.

40. Cremonini F, Di Caro S, Delgado-Aros S, et al. Meta-analysis: the relationship between Helicobacter pylori infection and gastro-oesophageal reflux disease. Aliment Pharmacol Ther 2003;18: 279-289.

41. Peek RM. Helicobacter pylori and gastroesophageal reflux disease. Curr Treat Options Gastroenterol 2004;7:59-70.

42. McColl KE, Dickson A, El-Nujumi A, El-Omar E, Kelman A. Symptomatic benefit 1-3 years after $H$. pylori eradication in ulcer patients: impact of gastroesophageal reflux disease. Am J Gastroenterol 2000;95:101-105.

43. Yaghoobi M, Farrokhyar F, Yuan Y, Hunt RH. Is there an increased risk of GERD after Helicobacter pylori eradication?: a meta-analysis. Am J Gastroenterol 2010;105:1007-1013 
44. Ishiki K, Mizuno M, Take S, et al. Helicobacter pylori eradication improves pre-existing reflux esophagitis in patients with duodenal ulcer disease. Clin Gastroenterol Hepatol 2004;2:474-479.

45. Suzuki H, Hibi T, Marshall BJ. Helicobacter pylori: present status and future prospects in Japan. J Gastroenterol 2007;42:1-15.

46. Kamada T, Haruma K, Kawaguchi H, Yoshihara M, Sumii K, Kajiyama $\mathrm{G}$. The association between antral $\mathrm{G}$ and $\mathrm{D}$ cells and mucosal inflammation, atrophy, and Helicobacter pylori infection in subjects with normal mucosa, chronic gastritis, and duodenal ulcer. Am J Gastroenterol 1998;93:748-752.

47. Lai CH, Poon SK, Chen YC, Chang CS, Wang WC. Lower prevalence of Helicobacter pylori infection with vacA sla, cagA-positive, and babA2-positive genotype in erosive reflux esophagitis disease. Helicobacter 2005;10:577-585.

48. Wu JC, Sung JJ, Chan FK, et al. Helicobacter pylori infection is associated with milder gastro-oesophageal reflux disease. Aliment Pharmacol Ther 2000;14:427-432.

49. Somi MH, Fattahi E, Fouladi RF, Karimi M, Bonyadi R, Baballou Z. An inverse relation between CagAt strains of Helicobacter pylori infection and risk of erosive GERD. Saudi Med J 2008;29:393-396.

50. Rajendra S, Ackroyd R, Robertson IK, Ho JJ, Karim N, Kutty KM. Helicobacter pylori, ethnicity, and the gastroesophageal reflux disease spectrum: a study from the East. Helicobacter 2007;12: 177-183.

51. Ghoshal UC, Tiwari S, Dhingra S, et al. Frequency of Helicobacter pylori and CagA antibody in patients with gastric neoplasms and controls: the Indian enigma. Dig Dis Sci 2008;53:1215-1222.

52. Manabe N, Yoshihara M, Sasaki A, Tanaka S, Haruma K, Chayama K. Clinical characteristics and natural history of patients with low-grade reflux esophagitis. J Gastroenterol Hepatol 2002; 17: 949-954.

53. Chourasia D, Misra A, Tripathi S, Krishnani N, Ghoshal UC. Patients with $H$. pylori infection have less severe gastroesophageal reflux disease (GERD): a study using endoscopy, 24-hour gastric and esophageal pH metry. Indian J Gastroenterol 2010 (In press)

54. Vicari JJ, Peek RM, Falk GW, et al. The seroprevalence of cagA-positive Helicobacter pylori strains in the spectrum of gastroesophageal reflux disease. Gastroenterology 1998;115:50-57.

55. Holtmann G, Adam B, Liebregts T. Review article: the patient with gastro-oesophageal reflux disease - lifestyle advice and medication. Aliment Pharmacol Ther 2004;20(suppl 8):24-27.

56. Iwakiri K, Hayashi Y, Kotoyori M, Kawakami A, Sakamoto C. Pathophysiology of GERD: mechanisms of gastroesophageal reflux and prolonged esophageal acid exposure time. Nippon Rinsho 2004;62:1427-1432.

57. Kamradt AE, Greiner M, Ghiara P, Kaufmann SH. Helicobacter pylori infection in wild-type and cytokine-deficient C57BL/6 and BALB/c mouse mutants. Microbes Infect 2000;2:593-597.

58. Cameron AJ, Lagergren J, Henriksson C, Nyren O, Locke GR 3rd, Pedersen NL. Gastroesophageal reflux disease in monozygotic and dizygotic twins. Gastroenterology 2002;122:55-59.

59. Mohammed I, Cherkas LF, Riley SA, Spector TD, Trudgill NJ. Genetic influences in gastro-oesophageal reflux disease: a twin study. Gut 2003;52:1085-1089.

60. Chourasia D, Achyut BR, Tripathi S, Mittal B, Mittal RD,
Ghoshal UC. Genotypic and functional roles of IL-1B and IL-1RN on the risk of gastroesophageal reflux disease: the presence of IL-1B-511*T/IL-1RN*1 (T1) haplotype may protect against the disease. Am J Gastroenterol 2009;104:2704-2713.

61. Queiroz DM, Guerra JB, Rocha GA, et al. IL1B and IL1RN polymorphic genes and Helicobacter pylori cagA strains decrease the risk of reflux esophagitis. Gastroenterology 2004;127:73-79.

62. de Vries DR, ter Linde JJ, van Herwaarden MA, Smout AJ, Samsom M. Gastroesophageal reflux disease is associated with the C825T polymorphism in the G-protein beta3 subunit gene (GNB3). Am J Gastroenterol 2009;104:281-285.

63. Gough MD, Ackroyd R, Majeed AW, Bird NC. Prediction of malignant potential in reflux disease: are cytokine polymorphisms important? Am J Gastroenterol 2005;100:1012-1018.

64. Kawamura M, Ohara S, Koike T, et al. The effects of lansoprazole on erosive reflux oesophagitis are influenced by CYP2C19 polymorphism. Aliment Pharmacol Ther 2003;17:965-973.

65. Casson AG, Zheng Z, Porter GA, Guernsey DL. Genetic polymorphisms of microsomal epoxide hydroxylase and glutathione S-transferases M1, T1 and P1, interactions with smoking, and risk for esophageal (Barrett) adenocarcinoma. Cancer Detect Prev 2006;30:423-431.

66. Liu B, Fan YJ, Wang ML, et al. Genetic polymorphisms in glutathione S-transferases T1, M1 and P1 and susceptibility to reflux esophagitis. Dis Esophagus 2006;19:477-481.

67. Casson AG, Zheng Z, Evans SC, et al. Cyclin D1 polymorphism (G870A) and risk for esophageal adenocarcinoma. Cancer 2005; 104:730-739.

68. Casson AG, Zheng Z, Evans SC, Veugelers PJ, Porter GA, Guernsey DL. Polymorphisms in DNA repair genes in the molecular pathogenesis of esophageal (Barrett) adenocarcinoma. Carcinogenesis 2005;26:1536-1541.

69. Wang F, Xia P, Wu F, et al. Helicobacter pylori VacA disrupts apical membrane-cytoskeletal interactions in gastric parietal cells. J Biol Chem 2008;283:26714-26725.

70. Uehara A, Okumura T, Okamura K, Takasugi Y, Namiki M. Lipopolysaccharide-induced inhibition of gastric acid and pepsin secretion in rats. Eur J Pharmacol 1990;181:141-145.

71. Tsuji K, Uehara A, Okumura T, et al. The gastric antisecretory action of lipopolysaccharide is blocked by indomethacin. Eur J Pharmacol 1992;210:213-215.

72. Helmer KS, West SD, Vilela R, et al. Lipopolysaccharide-induced changes in rat gastric H/K-ATPase expression. Ann Surg 2004; 239:501-509.

73. Higashi H, Yokoyama K, Fujii Y, et al. EPIYA motif is a membrane-targeting signal of Helicobacter pylori virulence factor CagA in mammalian cells. J Biol Chem 2005;280:23130-23137.

74. Brandt S, Kwok T, Hartig R, König W, Backert S. NF-kappaB activation and potentiation of proinflammatory responses by the Helicobacter pylori CagA protein. Proc Natl Acad Sci USA 2005; 102:9300-9305.

75. Yamaoka Y, Kwon DH, Graham DY. A M(r) 34,000 proinflammatory outer membrane protein (OipA) of Helicobacter pylori. Proc Natl Acad Sci USA 2000;97:7533-7588.

76. Satin B, Del Giudice G, Della Bianca V, et al. The neutrophil-activating protein (HP-NAP) of Helicobacter pylori is a pro- 
tective antigen and a major virulence factor. J Exp Med 2000; 191:1467-1476.

77. Ando T, El-Omar EM, Goto Y, et al. Interleukin 1B proinflammatory genotypes protect against gastro-oesophageal reflux disease through induction of corpus atrophy. Gut 2006;5 5:158-164.

78. Liu G, Zhou W, Yeap BY, et al. XRCC1 and XPD polymorphisms and esophageal adenocarcinoma risk. Carcinogenesis 2007;28: 1254-1258.

79. Abbas A, Delvinquiere K, Lechevrel M, et al. GSTM1, GSTT1, GSTP1 and CYP1A1 genetic polymorphisms and susceptibility to esophageal cancer in a French population: different pattern of squamous cell carcinoma and adenocarcinoma. World J Gastroenterol 2004;10:3389-3393.

80. Murphy SJ, Hughes AE, Patterson CC, et al. A population-based association study of SNPs of GSTP1, MnSOD, GPX2 and Barrett's esophagus and esophageal adenocarcinoma. Carcinogenesis 2007;28: 1323-1328.

81. Izzo JG, Wu TT, Wu X, et al. Cyclin D1 guanine/adenine 870 polymorphism with altered protein expression is associated with genomic instability and aggressive clinical biology of esophageal adenocarcinoma. J Clin Oncol 2007;25:698-707.

82. Rohof WO, Hirsch DP, Boeckxstaens GE. Pathophysiology and management of gastroesophageal reflux disease. Minerva Gastroenterol Dietol 2009;55:289-300.

83. Boeckxstaens GE. Review article: the pathophysiology of gastro-oesophageal reflux disease. Aliment Pharmacol Ther 2007; 26:149-160

84. Wang C, Hunt RH. Precise role of acid in non-erosive reflux disease. Digestion 2008;78(suppl 1):31-41.

85. Knowles $\mathrm{CH}$, Aziz Q. Visceral hypersensitivity in non-erosive reflux disease. Gut 2008;57:674-683.

86. Harris PR, Smythies LE, Smith PD, Dubois A. Inflammatory cytokine mRNA expression during early and persistent Helicobacter pylori infection in nonhuman primates. J Infect Dis 2000;181: 783-786.

87. Whary MT, Sundina N, Bravo LE, et al. Intestinal helminthiasis in Colombian children promotes a Th2 response to Helicobacter pylori: possible implications for gastric carcinogenesis. Cancer Epidemiol Biomarkers Prev 2005;14:1464-1469.

88. Lanas A, García-González MA,, Santolaria S, et al. TNF and LTA gene polymorphisms reveal different risk in gastric and duodenal ulcer patients. Genes Immun 2001;2:415-421.
89. Furuta T, El-Omar EM, Xiao F, Shirai N, Takashima M, Sugimura H. Interleukin 1beta polymorphisms increase risk of hypochlorhydria and atrophic gastritis and reduce risk of duodenal ulcer recurrence in Japan. Gastroenterology 2002;123:92-105.

90. Machado JC, Figueiredo C, Canedo P, et al. A proinflammatory genetic profile increases the risk for chronic atrophic gastritis and gastric carcinoma. Gastroenterology 2003;125:364-371.

91. Rad R, Prinz C, Neu B, et al. Synergistic effect of Helicobacter pylori virulence factors and interleukin-1 polymorphisms for the development of severe histological changes in the gastric mucosa. J Infect Dis 2003;188:272-281.

92. Basso D, Plebani M. H. pylori infection: bacterial virulence factors and cytokine gene polymorphisms as determinants of infection outcome. Crit Rev Clin Lab Sci 2004;41:313-337.

93. Garcia-Gonzalez MA, Strunk M, Piazuelo E, et al. TGFB1 gene polymorphisms: their relevance in the susceptibility to Helicobacter pylori-related diseases. Genes Immun 2006;7:640-646.

94. Achyut BR, Moorchung N, Mittal B. Genetic association of interleukin-1 haplotypes with gastritis and precancerous lesions in North Indians. Clin Exp Med 2008;8:23-29.

95. Schmausser B, Josenhans C, Endrich S, et al. Downregulation of CXCR1 and CXCR2 expression on human neutrophils by Helicobacter pylori: a new pathomechanism in $H$. pylori infection? Infect Immun 2004;72:6773-6779.

96. Gyulai Z, Klausz G, Tiszai A, et al. Genetic polymorphism of interleukin-8 (IL-8) is associated with Helicobacter pylori-induced duodenal ulcer. Eur Cytokine Netw 2004;15:353-358.

97. Xuan J, Deguchi R, Yanagi H, et al. Relationship between gastric mucosal IL-8 levels and histological gastritis in patients with Helicobacter pylori infection. Tokai J Exp Clin Med 2005; 30:83-88.

98. Nocon M, Labenz J, Willich SN. Lifestyle factors and symptoms of gastro-oesophageal reflux - a population-based study. Aliment Pharmacol Ther 2006;23:169-174.

99. Matsuzaki J, Suzuki H, Asakura K, et al. Gallstones increase the prevalence of Barrett's esophagus. J Gastroenterol 2009;45:171178.

100. Close LG. Laryngopharyngeal manifestations of reflux: diagnosis and therapy. Eur J Gastroenterol Hepatol 2002;14(suppl 1): S23-S27.

101. Terada K, Muro S, Sato S, et al. Impact of gastro-oesophageal reflux disease symptoms on COPD exacerbation. Thorax 2008;63: 951-955. 